\title{
The analysis of the Corylus, Alnus and Betula pollen seasons in Toruń in 2014 and 2016
}

\author{
Anna Filbrandt-Czaja*, Edyta Adamska \\ Nicolaus Copernicus University, Faculty of Biology and Environmental Protection, \\ Chair of Geobotany and Landscape Planning, Lwowska 1 St, 87-100 Toruń, Poland, \\ *e-mail: afczaja@umk.pl
}

Received: 26 March 2018 / Accepted: 8 May 2018

\begin{abstract}
The paper presents the results of the research on the pollen seasons of hazel (Corylus), alder (Alnus) and birch (Betula) in 2014 and 2016. The samples were collected gravimetrically at weekly intervals. The deposition values were converted into the pollen grains concentration in $1 \mathrm{~m}^{3}$ of air. The analysis of the pollen seasons was conducted based on the properties of the seasons: beginning, end, season duration, annual totals of pollen and maximum concentrations. The courses of the both compared pollen seasons differed. In 2014, the tree pollen season began two weeks later than in 2016, a year that was marked by high annual totals of pollen counts and maximum pollen concentrations of alder and birch. Only hazel showed higher values in 2014.
\end{abstract}

Key words: aerobiological monitoring in cities, early spring tree pollen, gravimetric method, pollen concentration.

\section{Introduction}

The pollen grains of hazel (Corylus), alder (Alnus) and birch (Betula) contain allergens that constitute a common cause of pollen allergy in Poland and other European countries (Rapiejko, 2008). Hazel and alder pollination occurs in the phenological early spring (Sokołowska, 1980), when the temperatures reach from $-10^{\circ} \mathrm{C}$ to $+15^{\circ} \mathrm{C}$. Birch blooms in the beginning of spring. The flowering of trees and shrubs in February and March is strongly determined by weather conditions. The onset and duration of flowering and pollination are subject to significant shifts in the individual years. A characteristic feature of allergic diseases caused by plants pollen allergens is a seasonal occurrence of the symptoms. The severity of the disease symptoms in pollen allergic individuals is closely related to the concentration of the aeroallergens in the air. Along with the increase of the concentration of the allergy-causing pollen grains, the severity of the symptoms also increases (Rapiejko, 2004).
For this reason, the monitoring of pollen concentration in the air is of the utmost importance in the effectiveness of the seasonal allergy treatment. The data from pollen monitoring allow for identifying the species causing the allergic reaction. It also allows for determining the most effective timing of the onset and completion of the allergen immunotherapy and for testing its efficacy (Rapiejko, 2006). The result of carrying out a pollen monitoring is a pollination calendar, or pollen calendar - a set of information on the plants pollen concentration in the air, over the period of one year, and in the individual geographical regions.

The aeropalynological studies for a medical use in Poland were initiated by Professor Mieczysław Obtułowicz. In 1936 he produced suggestions on etiology and treatment of pollen rhinitis and calendars of flowering and pollination of allergenic plants (grasses, trees) in the area of Kraków (http://www.aero.cm-uj.krakow.pl/historia-a.html).

The first pollen calendar in Poland has been created in 1947 by Mieczysław Dąbrowski (1974). During these years, an aerobiologic research was also carried out by 
Ryszard Gniazdowski (Bydgoszcz), Małgorzata Wnuk (Łódź), and Edward Zawisza (Warszawa). Currently, in Poland, there exists the Polish Aerobiological Network that conducts regular continuous aerobiological monitoring. The information on the pollen grains concentration is sent from monitoring stations located in several major Polish cities, such as: Kraków, Katowice, Lublin, Poznań, Łódź, Rzeszów and Szczecin, and also from cooperating research centres (http://www.aero.cm-uj.krakow.pl).

In the major cities in Poland, the aerobiological monitoring is also carried out by the Centre for Research on Environmental Allergens established in the 1980s. A period of appearance and disappearance of pollen grains of the given taxa can differ in individual regions of Poland, thus the smaller areas covered by the pollination calendar, the higher the certainty that the information provided in it is more precise (Rapiejko, 2006).

The research on the course of a pollen season in Torun has been conducted in 2014 (Worzała, 2015) and in 2016 (Kuras, 2017). Unfortunately, the results on the pollen season in Torun has not been published yet. The objective of this study is to present the results of the observations, carried out in Torun area, of pollination course of the trees which pollen is a common cause of pollinosis. Moreover, the aim of this paper is to compare the date of the start and end of the pollen season and total annual concentration of tree pollen in the air in Torun, observed in two years: 2014 and 2016.

\section{Study area}

Torun is located on the terraces of the Vistula River in the Torun Basin, in the place where the Vistula River valley intersects with the ice-marginal valley (Urstromtal) of the Drwęca and Noteć Rivers. The city is situated on both sides of the Vistula River, in the place where three geographic regions converge: the Kuyavian Lake District, the Chełmno Lake District and the Dobrzyń Lake District. In the southeast, Torun borders on the estuary section of the Drwęca River valley, and in the north - on the Chełmno Plateau. The most characteristic elements of the land relief in the city of Torun include ice-marginal and river valleys with the system of river terraces and scarps, and dune forms developed on the latter.

The city within the current administrative limits covers an area of over $115 \mathrm{~km}^{2}$ and has 191,227 inhabitants. The city is situated between $52^{\circ} 58^{\prime}$ and $53^{\circ} 04^{\prime}$ of north latitude, and $18^{\circ} 32^{\prime}$ and $18^{\circ} 43^{\prime}$ of east longitude. Torun is located in the central part of Kujawsko-Pomorskie Voivodeship; $220 \mathrm{~km}$ away from Warsaw and $175 \mathrm{~km}$ away from Gdańsk (Andrzejewski \& Kot, 2006).

Torun is located in the zone of warm temperate climate, a transitional climate between the oceanic climate of Western Europe and the continental climate of Eastern Europe and Asia. January is the coldest month $\left(-2.2^{\circ} \mathrm{C}\right)$ and the July is the warmest $\left(18.1^{\circ} \mathrm{C}\right)$ and the mean annual temperature amplitude amounts to $20.3{ }^{\circ} \mathrm{C}$. The mean annual sum of precipitation is $522.5 \mathrm{~mm}$. Climatic conditions of Torun are favourable for plant production. Zonal winds $\mathrm{W}(19.5 \%)$ and $\mathrm{E}(11.8 \%)$ dominate over meridian winds $\mathrm{N}$ and S (Wójcik \& Marciniak, 2006).

The city surrounding forests and good soils in the elevated areas around the Toruń Basin (Andrzejewski \& Kot, 2006).

Torun is rich in green areas, which cover ca. $30 \%$ of the city. Within the city limits there is a natural reserve - Kępa Bazarowa protects riverside forests. Unfortunately, as already mentioned by Rutkowski (2006), there is no concise, up-to-date survey of the vegetation in the city.

According to Burak et al. (2001), problems related to air pollution in Torun are connected with the increased concentration of traffic pollution in the city centre and along the main traffic routes. High concentration of particulate matter PM10 in the city, with clear seasonal differences and the maximum in winter, as well as persistent, increased concentration of $\mathrm{SO}_{2}$, especially in industrial areas and residential districts of detached houses, are also disturbing.

Annual concentration of sulphur and nitrogen oxides in Torun has declined since 2000, so in this respect the air quality in the city has been gradually improving (Wojtczak et al., 2007).

\section{Materials and methods}

Common hazel (Corylus avellana L.) is present in almost all Europe except northern Scandinavia. It grows all over Poland, even up to $1,000 \mathrm{~m}$ a.s.l. In terms of soil conditions, it is not a particularly demanding species, except for intolerance of waterlogged soils. It thrives, however, on more fertile soils, usually as the undergrowth in deciduous stands. It is also present in field scrubland, waterfront coppices and on dry hillsides (www.wlin.pl/las/atlas-drzew-ikrzewow/atlas-krzewow/leszczyna-pospolita).

In northern Poland, the genus Alnus Mill is represented only by two species, A. glutinosa (L.) Gaertner and A. incana (L.) Moench. The northern range of the two alder species growing in Poland differ. A. glutinosa is common throughout the country. However, it avoids higher altitudes in the mountains. A. incana is not so common; its sites are situated along the whole course of the Vistula River. Additionally, this species also has a northern centre extending from the Suwalki Lake District to the Tuchola Forest (Zając \& Zając, 2001).

In Poland, 7 birch species occur in the wild. Downy birch (B. pubescens) is common throughout the country; it grows on moderately fertile soils, on the banks of the 
water, often with the presence of alder. The most common species is European white birch (B. pendula). It is also the most popular deciduous tree used in landscaping, road planting and urban greenery. The flowering of birch trees occurs simultaneously with the development of leaves and takes place in April and May (Seneta, 1991).

Information on the occurrence of analyzed trees in Torun and the surrounding area is reported by Rutkowski (2006). Alnus glutinosa, for example, occurs in the form of small patches and belts, and only in the valley of Struga Rychnowska, Tążyna and Zielona grows in larger clusters. Besides, in Toruń and the surrounding area is commonly found Betula. All analyzed trees were also recorded in the reserves located in the vicinity of Toruń, e.g. in the Las Piwnicki reserve (Rejewski, 1996).

In Torun, the measurements of airborne pollen were carried out in 2014 (Worzała, 2015) and in 2016 (Kuras, 2017). The study on pollen fall of alder (Alnus), hazel (Corylus) and birch (Betula) was carried out in the area of the Nicolaus Copernicus University, in the building of the Faculty of Biology and Environmental Protection. The measurement of the pollen fall was conducted by the means of the gravimetric method with the use of two Petri dishes covered with glycerine and placed on a building's windowsill 5 metres above the ground level. The qualitative and quantitative estimations of the pollen grains deposited on dishes were conducted on a weekly basis. A single sample consisted of the material collected from two Petri dishes. The total surface area of both dishes was $72.6 \mathrm{~cm}^{2}$. 3-4 microscopic preparations were analysed from each sample. The results were converted into pollen grain deposition on the area of $1 \mathrm{~cm}^{2}\left(\mathrm{Pcm}^{-2}\right)$ a week because one tablet containing 18,584 Lycopodium spores (BATCH No.177745) was added to each sample. The values of the deposition were converted into the concentration of pollen grains in $1 \mathrm{~m}^{3}$ of air $\left(\mathrm{Pm}^{-3}\right)$ a week according to Omeliański formula (Dutkiewicz \& Jabłoński, 1989).

The date of the start and end of the pollen season, total annual concentration and the length of the season were determined for each taxon.

The pollen season was defined using the $90 \%$ method; the week on which the cumulative pollen count during the period between the 1st January and 30th June reached the value of $\geq 5 \%$ was determined to be the start date of the pollen season, and the end of the season was the week when the cumulative pollen count was $\geq 95 \%$ (Nilsson $\&$ Persson, 1991).

The total pollen count over this period was expressed by the symbol SPI (Seasonal Pollen Index).

\section{Results}

The analysis of the hazel, alder and birch pollen seasons was conducted based on the properties of the seasons: beginning, end, season duration, annual totals of pollen and maximum concentrations (Table 1, 2 and 3).

In 2016, the pollen season started three weeks earlier than in 2014. It was on the 3rd of February, whereas, in 2014 the first pollen grains were reported in the samples on the 24th of February (Table 1).

Table 1. Characteristics of hazel pollen season in Torun in 2014 and 2016

\begin{tabular}{|l|c|c|}
\hline \multicolumn{1}{|c|}{ Features of pollen season } & $\mathbf{2 0 1 4}$ & $\mathbf{2 0 1 6}$ \\
\hline $\begin{array}{l}\text { Pollen season period } \\
\text { by } 90 \% \text { method }\end{array}$ & $24.02-06.04$ & $03.02-30.03$ \\
\hline $\begin{array}{l}\text { Duration of pollen season } \\
\text { (number of weeks) }\end{array}$ & 6 & 7 \\
\hline $\begin{array}{l}\text { Seasonal Pollen Index (SPI) } \\
\text { total }\left(\mathrm{Pm}^{-3}\right)\end{array}$ & 1,336 & 636 \\
\hline Peak value $\left(\mathrm{Pm}^{-3}\right)$ & 847 & 179 \\
\hline Peak date & $23.03-30.03$ & $17.02-24.02$ \\
\hline
\end{tabular}

In 2014 hazel started to pollinate later than in 2016 (Fig. 1). The hazel pollen season commenced on week 24.02-03.03 and ended on week 06.04-13.04.

Initially, hazel reached the concentration of 168 grains per $1 \mathrm{~m}^{3}\left(\mathrm{Pm}^{-3}\right)$ of air, whereupon, there occurred a considerable decrease in this taxon's pollen grains concentration. During subsequent weeks, the count of the pollen grains has been increasing until 23-30.03.2014, when the maximum concentration of 847 grains per $1 \mathrm{~m}^{3}$ of air was reported. In the following week, that is, at the beginning of April, there occurred a considerable decrease in the concentration, amounting to only 18 grains per $1 \mathrm{~m}^{3}$ of air. In 2016, the hazel pollen season started on the 3rd of February and ended in the week 30.03-06.04. Initially, hazel reached concentration equal to 139 grains per 1 $\mathrm{m}^{3}$ of air. Subsequently, there occurred a decrease in this taxon's pollen grains concentration. Between 17.02 and 24.02 there occurred another increase in the pollen grains concentration. In the subsequent weeks, we can observe a gradual decrease in the hazel pollen grains concentration. A concentration level of 0-20 grains per $1 \mathrm{~m}^{3}$ continued from 23rd of March until the end of the pollen season.

In the following week, it was the opposite, the hazel pollen grains were more common in the samples from 2016. In the last week under the analysis, again in 2016 , the concentration of the pollen grains of this tree was lower than in 2014 


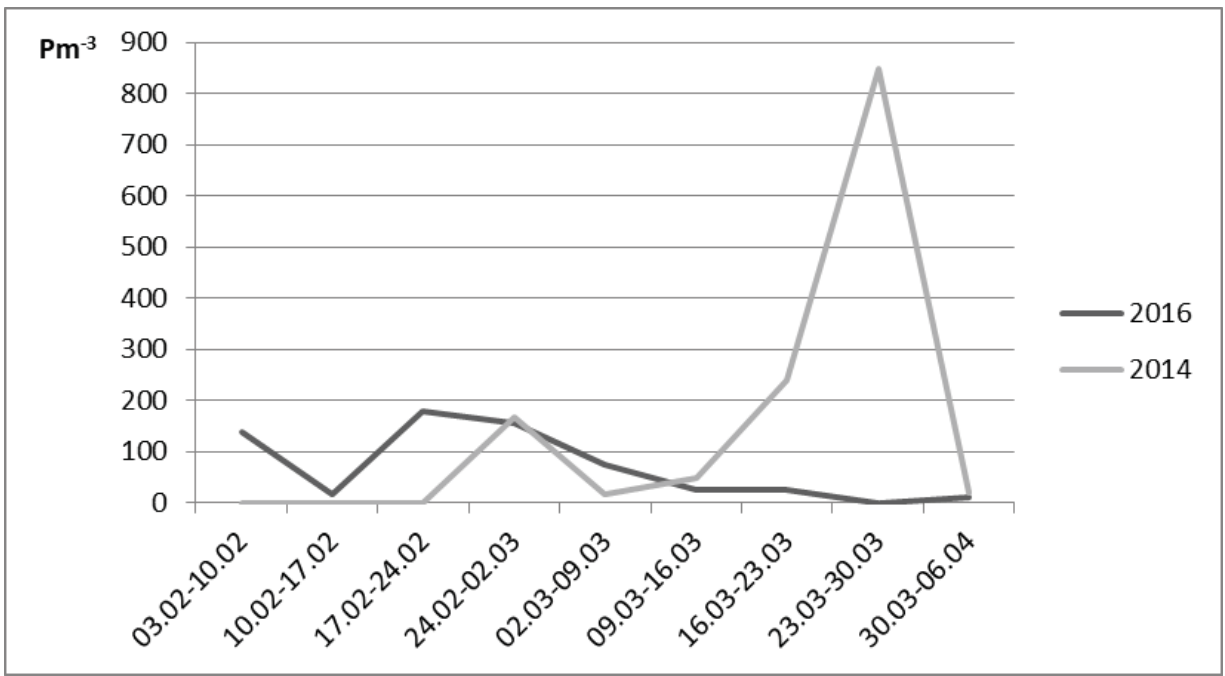

Figure 1. Hazel pollen concentration in Toruń in 2014 and 2016

Table 2. Characteristics of alder pollen season in 2014 and 2016

\begin{tabular}{|l|c|c|}
\hline \multicolumn{1}{|c|}{$\begin{array}{c}\text { Features of pollen } \\
\text { season }\end{array}$} & $\mathbf{2 0 1 4}$ & $\mathbf{2 0 1 6}$ \\
\hline $\begin{array}{l}\text { Pollen season period } \\
\text { by } 90 \% \text { method }\end{array}$ & $24.02-06.04$ & $03.02-27.04$ \\
\hline $\begin{array}{l}\text { Duration of pollen season } \\
\text { (number of weeks) }\end{array}$ & 7 & 12 \\
\hline $\begin{array}{l}\text { Seasonal Pollen Index (SPI) } \\
\text { total }\left(\mathrm{Pm}^{-3}\right)\end{array}$ & 5,798 & 12,847 \\
\hline Peak value $\left(\mathrm{Pm}^{-3}\right)$ & 1,340 & 3,353 \\
\hline Peak date & $30.03-06.04$ & $02.03-09.03$ \\
\hline
\end{tabular}

In 2016, alder reached a considerably higher airborne concentration of the pollen grains than in 2014 (Fig. 2).

In 2014, between 24.02 and 02.03 , it amounted to 1,270 grains in $1 \mathrm{~m}^{3}$ of air, whereas in 2016 , as many as 2,088 grains. The highest difference at the beginning of the pollen season of alder in the both years was observed in the week between 2nd and 9th of March. In 2016, the grains concentration in $1 \mathrm{~m}^{3}$ was 3,353, whilst in 2014 it was only 618 (Fig. 2). Although these results show a very high airborne concentration of the pollen grains, an evident difference can be noted between the two years compared.

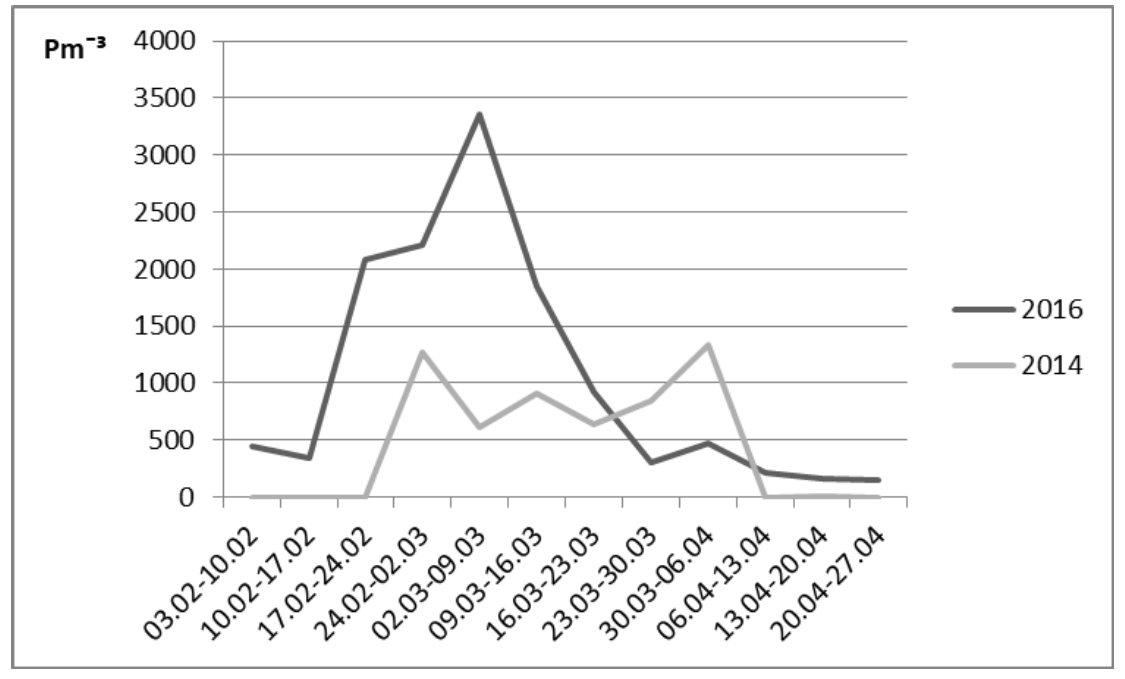

Figure 2. Alder pollen concentration in Toruń in 2014 and 2016 
Table 3. Characteristics of birch pollen season in 2014 and 2016

\begin{tabular}{|l|c|c|}
\hline \multicolumn{1}{|c|}{$\begin{array}{c}\text { Features of pollen } \\
\text { season }\end{array}$} & $\mathbf{2 0 1 4}$ & $\mathbf{2 0 1 6}$ \\
\hline $\begin{array}{l}\text { Pollen season period } \\
\text { by } 90 \% \text { method }\end{array}$ & $23.03 .-01.06$ & $23.03 .-01.06$ \\
\hline $\begin{array}{l}\text { Duration of pollen season } \\
\text { (number of weeks) }\end{array}$ & 10 & 10 \\
\hline $\begin{array}{l}\text { Seasonal Pollen Index } \\
\left(\text { SPI) total }\left(\mathrm{Pm}^{-3}\right)\right.\end{array}$ & 15,331 & 26,822 \\
\hline Peak value $\left(\mathrm{Pm}^{-3}\right)$ & 7,460 & 12,292 \\
\hline Peak date & $13.04-20.04$ & $06.04-13.04$ \\
\hline
\end{tabular}

100 grains per $1 \mathrm{~m}^{3}$ of air. Such concentration has been reported from 21.04.2014 to the end of May in the same year. Whereas, in 2016, the birch pollen grains occurred in the week between the 16th and 23rd of March. It was merely 5 grains per $1 \mathrm{~m}^{3}$. The highest airborne concentration of the birch pollen grains was recorded in the week between 6th and 13th of April and amounted to 12,292 grains per $1 \mathrm{~m}^{3}$. In the following weeks, a significant decrease in the concentration of the pollen grains of this tree was recorded. Despite the noticeable decrease in the birch pollen grains count in the air, the concentration was still relatively high, and by the end of April, it amounted to approximately 2,000 $\mathrm{Pm}^{-3}$.

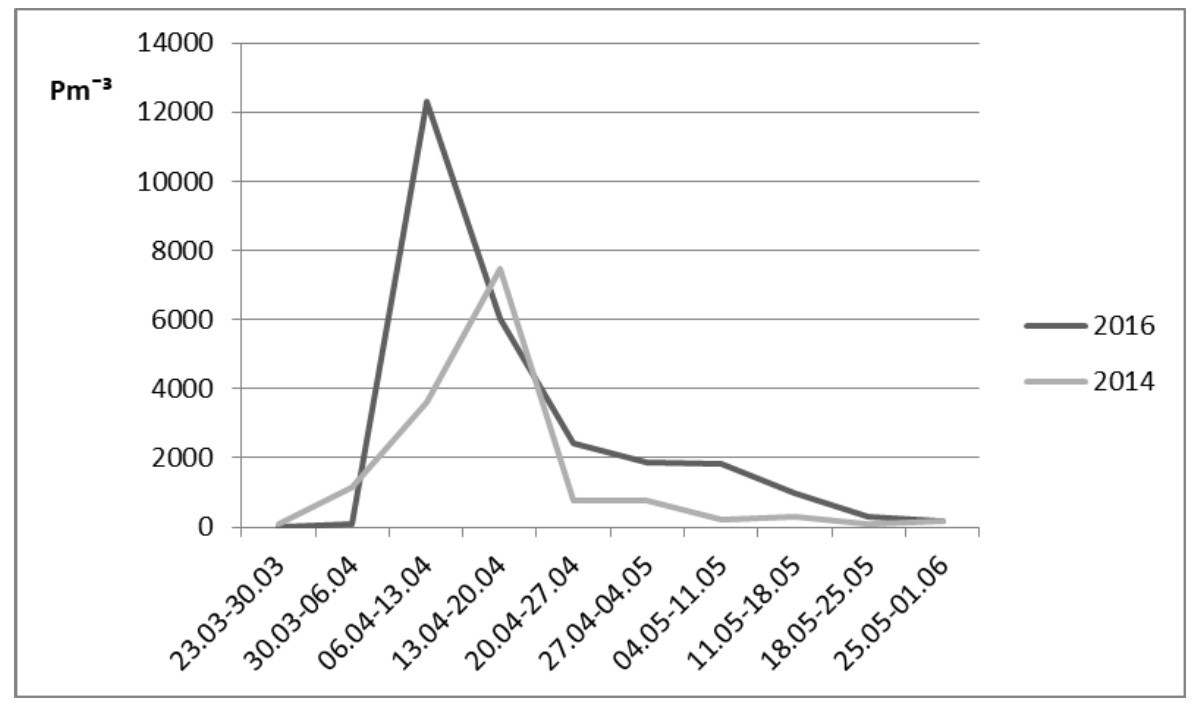

Figure 3. Birch pollen concentration in Toruń in 2014 and 2016

In 2014, the birch pollen grains started to occur in the samples on the 23th of March. At the very beginning of the pollen season, the concentration of the birch pollen grains remained at the level below 100 grains per $1 \mathrm{~m}^{3}$ (Fig. 3).

In 2014 a noticeable increase in this genus pollen grains concentration occurred in the first week of April $\left(1,164\right.$ grains per $\left.1 \mathrm{~m}^{3}\right)$. Since then, the concentration increased until it reached its peak in the third week of April when birch released 7,460 pollen grains per $1 \mathrm{~m}^{3}$ of air into the atmosphere. In the following weeks, in relation to the second half of April, a significant decrease of the pollen grains concentration was reported. It is, though, worth to mention that despite the relevant decrease of the birch pollen grains count in the air, the concentration remained on a relatively high level, that is, it exceeded

\section{Discussion}

In the analysed seasons, from the three analysed genres, the pollen grains of hazel occurred in the air the earliest. In 2014, the hazel pollen grains were observed in the last week of February, and in 2016 in the first week of February. It is worth to mention that the hazel pollen grains very often occur in the air at the beginning of February, and even in mid-January (Rapiejko, 2006). In 2016, the hazel pollen season began very early in many cities in Poland such as Opole and Zielona Góra, as early as the end of December 2015 (Piotrowska-Weryszko et al., 2016). It depends on a number of weather factors, such as sun exposure or temperature that is considered one of the most 
important weather elements determining the beginning of a pollen season (Dąbrowska, 2008; Emberlin et. al., 2007). Research results of Gonzales et al. (1999), Emberlin et al. (2002) and Peternel et al. (2005) indicate that the main meteorological factor deciding about the starting date of pollen seasons in alder, hazel and birch is the temperature. Based on over a dozen years of observations, it has been found that the beginning of the hazel pollen seasons in Poznań varied greatly, with almost 3 months difference between the earliest and latest start dates during the study period (Grewling et al., 2014).

The beginning of February 2016 (Fig. 4) was characterised by a relatively high temperature, which, without doubt, resulted in the earlier beginning of the hazel pollen season than in 2014 .

In the following weeks, however, generally higher temperature occurred in 2014 . It probably resulted in the fact that in 2016 the maximum weekly concentration of the hazel pollen grains was considerably lower than in 2014 and amounted merely to $179 \mathrm{Pm}^{-3}$. Whereas, in 2014 it was as many as 847 grains in $1 \mathrm{~m}^{3}$ of air.

For example, in 2014 pollen grains were released early by hazel in Bydgoszcz where individual pollen grains of this genus were observed as early as at the beginning of January, whereas the pollen season started on the 7 th of February (Jurkiewicz et al., 2014). Thus a conclusion can be drawn that the weather conditions in Torun, at the beginning of February 2014 were not sufficiently favourable for hazel in terms of pollination, resulting in a slight delay of its polling season.

In the both analysed seasons, along with the occurrence of the hazel pollen grains in the air, also alder pollen grains were observed which concentrations reached very high levels from the beginning. Other year-on-year differences in the pollen season start date may be due to high temperatures during the freezing period and low temperatures during heat accumulation (Jato et al., 2000). The course of the alder pollen season during the both years compared differed. In 2014, alder pollen remained in the air for seven weeks reaching the maximum weekly concentration of 1,340 grains in $1 \mathrm{~m}^{3}$ of air and SPI of 5,798 $\mathrm{Pm}^{-3}$. Whereas in 2016, the alder pollen season continued for 12 weeks and its weekly maximum was 3,353 pollen grains in $1 \mathrm{~m}^{3}$ of air, and SPI reached a value of 12,847 . In 2014, the alder pollen season started late and ended early. Such relations between the beginning and the duration of the tree pollen seasons were also reported by Dąbrowska-Zapart \& Chłopek (2014). Usually, in the years when the seasons started late, the duration of the pollen seasons decreased. The same relationship for hazel was reported by Piotrowicz \& Myszkowska (2006).

In 2016, at a similar time as in Torun, the alder pollen season commenced in Bydgoszcz (Puc et al., 2016). The Seasonal Pollen Index (SPI) in this city was slightly lower, whereas, similar values of SPI at the time were reported in Olsztyn and Poznań (Puc et al., 2016). In Bydgoszcz, in 2014, the first pollen grains from alder were observed as soon as in January, while the11th of February was considered as the beginning of the pollen season. In the both cities, the concentration of the alder pollen grains was significantly higher than what was reached by hazel (Jurkiewicz et al., 2014). It is certainly related not only to the count of the specimen present in the given area but also to the higher potential of producing pollen grains in the case of alder. Moreover, it is worth to point out that in Poland there is only one hazel species living in the wild, whereas in the case of alder, there are as many as three species of this genus present in the country (Rapiejko, 2008).

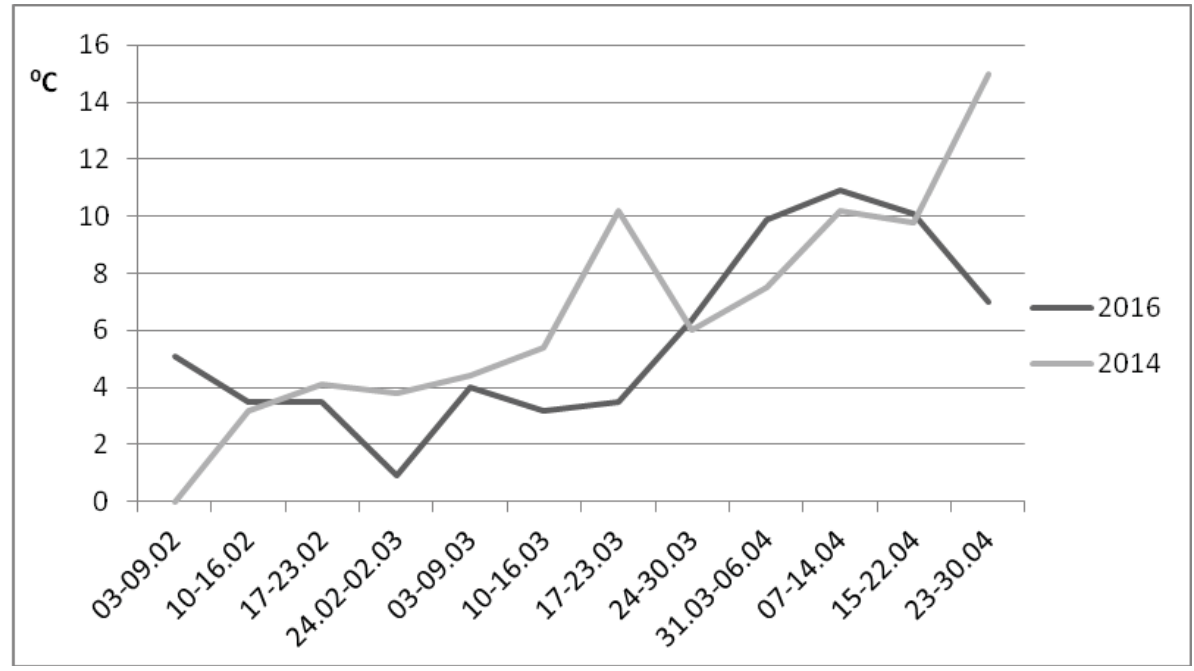

Figure 4. Average weekly temperature during the period of tree pollination in the compared years 
By the end of March, the birch pollen grains started to appear in the air. Their concentration was high from the beginning. However, the first considerable increase in their concentration in 2014 was observed in the week between 30th of March and 6th of April, when 1,164 pollen grains per $1 \mathrm{~m}^{3}$ of air were reported. In the following week, the concentration increased threefold, but the maximum value was observed in mid-April when the concentration amounted to 7460 grains per $1 \mathrm{~m}^{3}$ of air. In the same year, in Bydgoszcz, the maximum concentration of birch pollen grains was approximately1,500 grains per $1 \mathrm{~m}^{3}$ of air (Jurkiewicz et al., 2014). However, these two values cannot be compared directly, since in Torun the samples were collected every week, whereas in Bydgoszcz, a daily airborne pollen concentration was recorded. Considering the duration of the birch pollen season in 2014, it was similar in the two cities. The pollination began in mid-March and continued until mid-May in Bydgoszcz (Jurkiewicz et al., 2014), and until the end of May, in Torun (Fig. 3). In 2016, the birch pollen season started at the same time as in 2014, but the course of the pollen season of the trees of this genus in the both compared years was not the same. 2016 was characterised by higher maximum values and the annual sum (SPI). In many cities in Poland, that year was also marked by extremely high birch pollen concentration (WeryszkoChmielewska et.al., 2016). In 2016, also a higher cumulative early spring tree pollen concentration was recorded for the majority of the weeks of their pollination (Fig. 5). It results from remarkably high pollen concentration of birch as well as alder, reported in that year.
Birch pollen was present in the air even after the end of the season, that is, in the period between June and August, as an effect of so-called redeposition, a far transport of pollen or a breakup of fruiting bodies (Szczepanek, 1994).

The late occurrence of the pollen grains of this genus could have been related to the far transport. Generally, the pollen grains present in the samples originate in the areas approximately $10 \mathrm{~km}$ distant, however, the occurrence in the air of pollen grains originated in significantly further areas cannot be ruled out. The occurrence of the pollen grains is being recorded even in the samples collected from the air above the Atlantic Ocean, in the areas few hundred kilometres away from the allergenic plants. Another example is Finland where as much as $70 \%$ share in the pollen grains recorded belonged to birch tree which does not occur in this country. In the Arctic, the occurrence of pine pollen grains is recorded; the grains had to travel a distance of as many as $3000 \mathrm{~km}$ to reach this area of the globe (Majkowska-Wojciechowska \& Wojciechowska, 2008). While comparing the properties of the analysed early spring tree pollen seasons in Torun: beginning, end, season duration, annual totals of pollen and the maximum concentrations, significant differences between them were observed. In the moderate climate zone, in Northern and Central Europe, the pollen seasons of the trees flowering in early spring are characterised by evident variability in consecutive years (Jäger et al., 1996). The dates of the beginnings of these taxa pollen seasons in some years varied even by more than two months, whereas, the dates of the season ends differed by over a month, in the case of hazel, and by al-

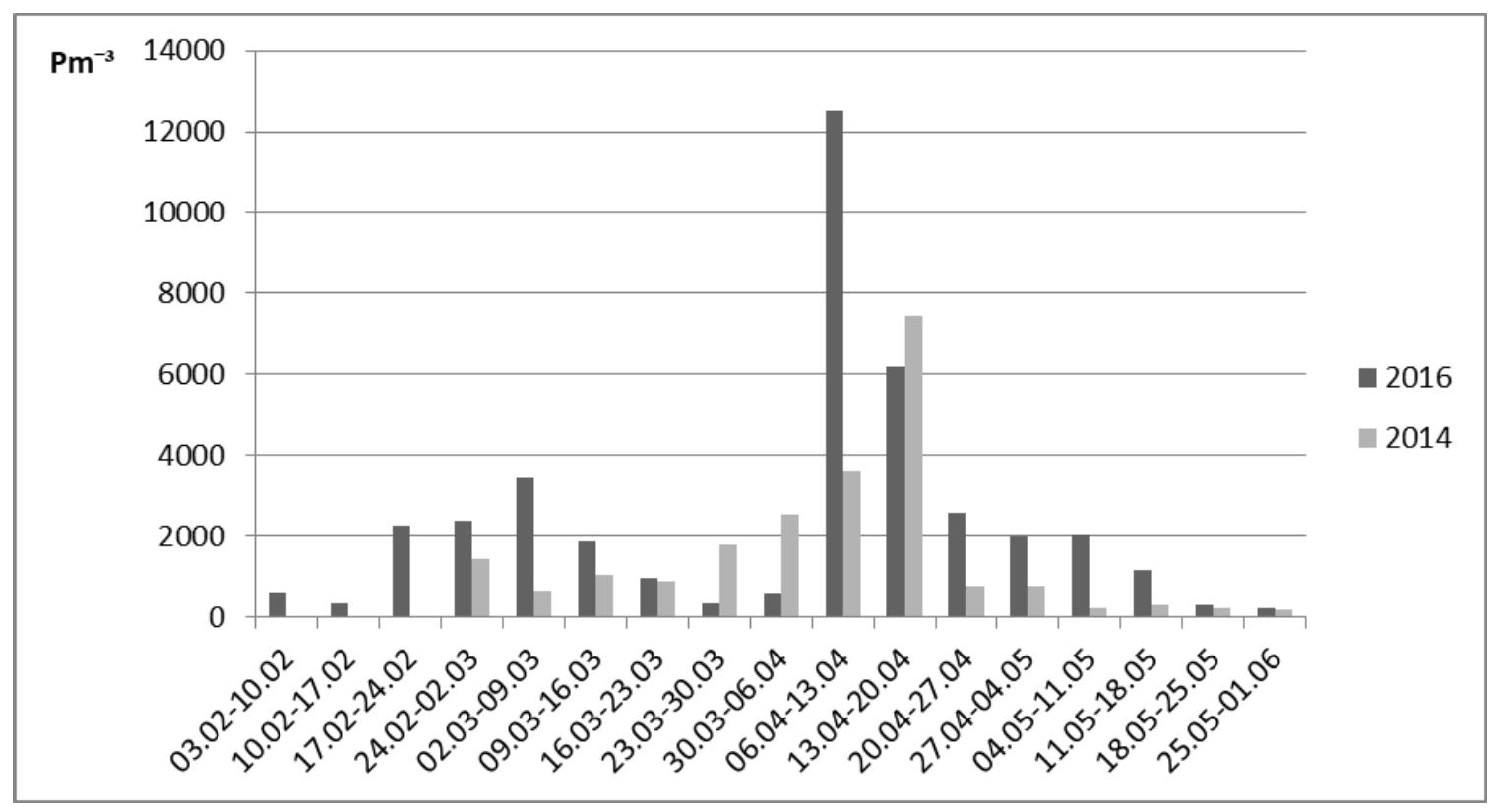

Figure 5. The weekly totals for the pollen concentrations of the trees — birch, alder and hazel in 2014 and 2016 
most two months, in the case of alder. In various regions of the country, a similar phenomenon was also observed by Kasprzyk (2006), Stach (2006) and Szczepanek (2006), Weryszko-Chmielewska \& Piotrowska (2006).

\section{Conclusions}

In 2014 and 2016 in Torun, the course of the pollen season of hazel, alder and birch differed.

In 2014, the tree pollen season started two weeks later than in 2016.

2016 was marked by high annual totals of the pollen count and maximum concentrations for alder and birch. Only hazelnut showed higher values in 2014.

The comparison of the tree pollen seasons in Torun with other cities showed numerous differences, thus confirming the fact that the observations of pollen appearance and occurrence in the air are of local character, thus, the smaller the plant pollination study areas, the higher reliability of the information acquired. Therefore, it can be applied in the treatment and diagnosis of allergies.

\section{References}

Andrzejewski L. \& Kot R., 2006, O położeniu Torunia [Location of Toruń], [in:] L. Andrzejewski, P. Weckwerth \& Sz. Burak (eds), Toruń i jego okolice. Monografia przyrodnicza [Toruń and its surroundings. Nature Monograph]. UMK, Toruń: 27-34.

Burak Sz., Hildebrandt K. \& Wojtczak H., 2001, Ocena stanu środowiska miasta Torunia. Część I, [in:] Sz. Burak (ed.), Ocena stanu środowiska Miasta Torunia. Urząd Miasta w Toruniu, Polski Klub Ekologiczny, Okręg Pomorsko-Kujawski, Toruń: 5-56.

Dąbrowska A., 2008, The influence of weather conditions on the course of pollen seasons of alder (Alnus spp.), hazel (Corylus spp.) and birch (Betula spp.). Acta Agrobotanica 61(1): 53-57.

Dąbrowska-Zapart K. \& Chłopek K., 2014, Dynamika sezonów pyłkowych wybranych taksonów roślin w powietrzu Sosnowca w latach 2001-2013 [Dynamics of pollen seasons of selected taxa of plants in the air of Sosnowiec in the years 2001-2013], [in:] E. WeryszkoChmielewska (ed.), Ziarna pyłku i zarodniki grzybów w powietrzu różnych regionów Polski [Pollen grains and fungal spores in the air of various regions of Poland]. PTB, Warszawa: 47-62.

Dąbrowski M.J., 1974, Recensement pollinique en Pologne. Pollen calendar for Poland, [in:] J. Charpin, R. Surinyach, A. W. Frankland (eds), Atlas Européen des pollens allergisants, Sandoz Éditions, Paris: 65-169.
Dutkiewicz J. \& Jabłoński L., 1989, Biologiczne Szkodliwości Zawodowe [Biological vocational harmfulness]. PZWL, Warszawa.

Emberlin J, Smith M, Close R. \& Adams-Groom B., 2007, Changes in the pollen seasons of the early flowering trees Alnus spp. and Corylus spp. in Worcester United Kingdom 1996-2005. Int. J. Biometeorol. 51: 181-191.

Emberlin J., Detandt M., Gehring R., Jaeger S., Nolard N. \& Rantio-Lehtimaki A., 2002, Responses in the start of Betula (birch) pollen season to recent changes in spring temperatures across Europe. Int. J. Biometeorol. 46: 159-170.

Gonzalez Minero F. J, Morales J., Tomas C. \& Candau P., 1999, Relationship between air temperature and the start of pollen emission in some arboreal taxa in Southwestern Spain, Grana 38: 306-310.

Grewling Ł., Jenerowicz D., Nowak M., Polańska A., Jackowiak B., Czarnecka-Operacz M. \& Smith M., 2014, Clinical relevance of Corylus pollen in Poznań, western Poland. Ann. Agric. Environ. Med. 21(1): 64-69.

Jato V., Frenguelli G., Rodriguez-Rajo F.J. \& Aira M.J., 2000, Temperature requirements of Alnus pollen in Spain and Italy (1994-1998). Grana 39: 240-245.

Jäger S., Nilsson S., Berggren B., Pessi A.-M., Helander M. \& Ramfjord H., 1996, Trends of some airborne tree pollen in the Nordic countries and Austria, 19801993. Grana 35(3): 171-178.

Jurkiewicz D., Lipiec A., Rapiejko P. \& Woźniak-Kosek A., 2014, Sezon pylenia leszczyny, olszy i brzozy w Bydgoszczy w 2014 roku [The hazel, alder and birch pollination season in Bydgoszcz in 2014]. Alergoprofil 10(2): 13-16.

Kasprzyk I., 2006, Pyłek wybranych taksonów roślin w powietrzu Rzeszowa, 2001-2005, [in:] E. Weryszko-Chmielewska (ed.), Pyłek roślin [Pollen of selected taxa of plants in the air of Rzeszów, 2001-2005] w aeroplanktonie różnych regionów Polski [Pollen of plants in the aeroplankton of various regions of Poland]. Katedra i Zakład Farmakognozji z Pracownią Roślin Leczniczych Wydziału Farmaceutycznego Akademii Medycznej im. prof. F. Skubiszewskiego, Chair and Department of Pharmacognosy with the Laboratory of Medicinal Plants of the Faculty of Pharmacy of the Medical Academy of the name of prof. F. Skubiszewski, Lublin: 93-103.

Kuras K., 2017, Pyłek roślin alergennych w powietrzu Torunia w roku 2016, Manuskrypt pracy magisterskiej [Pollen of allergenic plants in the air of Torun in 2016, Manuscript of the Master Thesis]. Nicolaus Copernicus University, Faculty of Biology and Environmental Protection, Chair of Geobotany and Landscape Planning, Toruń. 
Majkowska-Wojciechowska B. \& Wojciechowska A., 2008, Aerobiologia - kierunki badań i wyzwania XXI wieku [Aerobiology - directions of research and challenges of the 21 st century]. Alergia Astma Immunologia 13(3): 142-150.

Nilsson S. \& Persson S., 1991, Tree pollen spectra in the Stockholm region (Sweden) 1973-1980. Grana 20: 179182.

Peternel R., Srnec L., Hrga I., Hercog P. \& Čulig J., 2005, Airborne pollen of Betula, Corylus and Alnus in Zagreb, Croatia. A three-year record. Grana 44: 187-191.

Piotrowicz K. \& Myszkowska D., 2006, The start date, end and duration of the hazel pollen seasons on the background of climatic changes in Krakow. Alergologia Immunologia 3(3-4): 86-89.

Piotrowska-Weryszko K., Weryszko-Chmielewska E., Sulborska A., Żuraw B., Rapiejko A., Gawlik R., Chłopek K., Ziemianin M., Malkiewicz M., \& Maciejewska E., 2016, Corylus pollen season in southern Poland in 2016. Alergoprofil 12(2): 87-91.

Puc M., Lipiec A., Stacewicz A., Rapiejko P., Wolski T., Siergiejko G., Świebocka E.M., Kosek J., Jurkiewicz D. \& Szymańska A., 2016, The analysis of alder pollen season in northern Poland in 2016. Alergoprofil 12(2): 92-95.

Rapiejko P., 2004, Pyłek roślin jako źródło alergenów [Plant pollen as a source of allergens]. Przegląd Alergologiczny 1: 7-12.

Rapiejko P., 2006, Aerobiologia medyczna [Medical aerobiology]. Alergia, Astma, Immunologia 11(2): 76-82.

Rapiejko P., 2008, Alergeny pyłku roślin [Allergens of plant pollen]. Medical Education, Warszawa.

Rejewski M., 1996, Las Piwnicki [Piwnicki Forest], [in:] M. Rejewski, P. Bielecki (eds), Rezerwaty przyrody województwa toruńskiego [Natural Reserves in the Province of Toruń]. Urząd Wojewódzki w Toruniu, Wydział Ochrony Środowiska, Wojewódzki Konserwator Przyrody, Toruń: 85-90.

Rutkowski L., 2006, Szata roślinna [Plant cover], [in:] L. Andrzejewski, P. Weckwerth, Sz. Burak (eds), Toruń i jego okolice. Monografia przyrodnicza [Torun and its surroundings. Nature Monograph]. UMK, Toruń: $177-$ 189.

Seneta W., 1991, Drzewa i krzewy liściaste, T. 1 [Deciduous trees and shrubs, Vol. 1]. PWN, Warszawa.

Sokołowska J., 1980, Przewodnik fenologiczny [A phenological guidebook]. Wydawnictwa Komunikacji i Łączności, Warszawa.

Stach A., 2006, Pyłek wybranych taksonów roślin w powietrzu Poznania, 2001-2005 [Pollen of selected taxa in air in Poznań, 2001-2005], [in:] E. Weryszko-Chmielewska (ed.), Pyłek roślin w aeroplanktonie różnych regionów Polski [Pollen of plants in the aeroplankton of various regions of Poland]. Katedra i Zakład Farmakognozji z Pracownią Roślin Leczniczych Wydziału Farmaceutycznego Akademii Medycznej im. prof. F. Skubiszewskiego, Chair and Department of Pharmacognosy with the Laboratory of Medicinal Plants of the Faculty of Pharmacy of the Medical Academy of the name of prof. F. Skubiszewski, Lublin: 31-47.

Szczepanek K., 1994, Pollen calendar for Cracow (southern Poland), 1982-1991. Aerobiologia 10(1): 65-70.

Szczepanek K., 2006, Pyłek wybranych taksonów roślin w powietrzu Krakowa, 1993-1997 (metoda grawimetryczna) [Pollen of selected taxa in air in Kraków, 1993-1997 (gravimetric metod)], [in:] E. Weryszko-Chmielewska (ed.), Pyłek roślin w aeroplanktonie różnych regionów Polski [Pollen of plants in the aeroplankton of various regions of Poland]. Katedra i Zakład Farmakognozji z Pracownią Roślin Leczniczych Wydziału Farmaceutycznego Akademii Medycznej im. prof. F. Skubiszewskiego, Chair and Department of Pharmacognosy with the Laboratory of Medicinal Plants of the Faculty of Pharmacy of the Medical Academy of the name of prof. F. Skubiszewski, Lublin: 13-20.

Weryszko-Chmielewska E. \& Piotrowska K., 2006, Pyłek wybranych taksonów roślin w powietrzu Lublina w latach 2001-2005 [Pollen of selected taxa of plants in the air of Lublin in 2001-2005], [in:] E. Weryszko-Chmielewska (ed.), Pyłek roślin w aeroplanktonie różnych regionów Polski [Pollen of plants in the aeroplankton of various regions of Poland]. Katedra i Zakład Farmakognozji z Pracownią Roślin Leczniczych Wydziału Farmaceutycznego Akademii Medycznej im. prof. F. Skubiszewskiego, Chair and Department of Pharmacognosy with the Laboratory of Medicinal Plants of the Faculty of Pharmacy of the Medical Academy of the name of prof. F. Skubiszewski, Lublin: 105-115.

Weryszko-Chmielewska E., Piotrowska-Weryszko K., Haratym W., Żuraw B., Lipiec A., Gawlik R., Chłopek K., Malkiewicz M., Ziemianin M. \& Maciejewska E., 2016, Betula pollen season in southern Poland in 2016. Alergoprofil 12(2): 96-100.

Wojtczak H., Solarczyk A., Hildebrandt K., Jankowski J. \& Piotrowiak P., 2007, Stan środowiska miasta Torunia w 2006 roku. Wojewódzki Inspektorat Ochrony Środowiska w Bydgoszczy, Delegatura w Toruniu. (www.wios.bydgoszcz.pl/pdf/torun2006.pdf).

Worzała E., 2015, Występowanie alergenów pyłkowych w powietrzu na terenie Torunia, Manuskrypt pracy magisterskiej [Occurrence of pollen allergens in the air in Toruń, Manuscript of the Master Thesis]. Nicolaus Copernicus University, Faculty of Biology and Environmental Protection, Chair of Geobotany and Landscape Planning, Toruń. 
Wójcik G. \& Marciniak K., 2006, Klimat [Climate], [in:] L. Andrzejewski, P. Weckwerth, Sz. Burak (eds), Toruń i jego okolice. Monografia przyrodnicza [Toruń and its surroundings. Nature Monograph]. UMK, Toruń: 99-128. www.aero.cm-uj.krakow.pl [Accessed 02.02.2018].

www.aero.cm-uj.krakow.pl/historia-a.html [Accessed 02.05.2018]. www.wlin.pl/las/atlas-drzew-i-krzewow/atlas-krzewow/ leszczyna-pospolita [Accessed 12.02. 2018].

Zając A. \& Zając M., 2001, Atlas rozmieszczenia roślin naczyniowych w Polsce [Distribution Atlas of Vascular Plant of Poland]. Pracownia Chorologii Komputerowej, Instytut Botaniki Uniwersytetu Jagiellońskiego, Kraków. 